УДК 656.224

\title{
ФОРМУВАННЯ ЦІЛЬОВОЇ ФУНКЦІЇ ЕКСПЛУАТАЦІї ШВИДКІСНИХ ПОЇЗДІВ
}

\author{
Канд. техн. наук Г. С. Бауліна, В. С. Левченко \\ ФОРМИРОВАНИЕ ЦЕЛЕВОЙ ФУНКЦИИ ЭКСПЛУАТАЦИИ СКОРОСТНЫХ \\ ПОЕЗДОВ
}

Канд. техн. наук А. С. Баулина, В. С. Левченко

\section{FORMATION OBJECTIVE FUNCTION FOR EXPLOITATION OF HIGH-SPEED TRAIN}

\author{
Phd. tehn. G. Baulina, V. Levchenko
}

Розглянуто особливості розвитку швидкісного руху в Україні, проаналізовано обсяги перевезень пасажирів $і$ встановлено, що одним із напрямків забезпечення подальшого зростання кількості перевезень є збільшення швидкостей руху пасажсирських поӥздів. Сформовано иілььову функиію експлуатації швидкісних поїздів, яка дозволяє визначити оптимальне значення середньої швидкості руху при безупинному пропуску швидкісного поїза із забезпеченням мінімальних витрат на перевезення.

Ключові слова: швидкісний поӥз, чільова функція, середня швидкість руху.

Рассмотрены особенности развития скоростного движения в Украине, проанализированы объемы перевозок пассажиров и установлено, что одним из направлений обеспечения дальнейшего роста перевозок является увеличение скоростей движения пассажирских поездов. Сформирована целевая функиия эксплуатации скоростных поездов, которая позволяет определить оптимальное значение средней скорости движения при безостановочном пропуске скоростного поезда с обеспечением минимальных затрат на перевозку.

Ключевые слова: скоростной поезд, целевая функция, средняя скорость движения.

The features of the development of high-speed movement in Ukraine. Increasing volumes of passenger traffic in high-speed trains suggest that they are in great demand among the population. But today, the railways have not fully comply with modern requirements for transport, especially for the duration of travel. The maximum permitted speed of trains on the railways remains low compared to European railways. Analysis of passenger traffic volumes proved that one of the ways to ensure continued traffic growth is to increase the speeds of passenger trains.

Formed objective function operation of high-speed trains, which allows you to determine the optimal value of the average speed during non-stop passage of high-speed train with the lowest cost for transportation. Based on researches, the benefits of rapid transit and world experience can be argued that Ukraine would be appropriate and beneficial to further the implementation of highspeed traffic.

Keywords: high-speed train, the objective function, average speed traffic.

Вступ. Сучасне залізничне сполучення неможливо без високих швидкостей як основи інноваційного розвитку залізниць та ефективного інструменту для вирішення важливих соціально-економічних завдань в масштабах всієї держави. Повна реалізація проектів швидкісного і високошвидкісного руху зробить вагомий внесок в усунення 
«вузьких місць» транспортної системи України і дозволить зняти ряд обмежень економічного зростання за рахунок збільшення бюджетних доходів, розвитку вітчизняного машинобудування, туризму та інших суміжних галузей економіки.

Аналіз останніх досліджень i публікацій. Автор статті [1] стверджує, що розбудова на території України швидкісних та високошвидкісних магістралей створить ряд конкурентних переваг не лише для залізничного транспорту, а й всієї економіки країни за рахунок залучення додаткових обсягів транзитних вантажів. Саме тому реалізація необхідних заходів дозволить досягти синергетичного ефекту, який, 3 одного боку, буде проявлятися в підвищенні швидкості руху на магістралях країни, 3 іншого - в покращенні якості перевезень та підвищенні рівня їх безпеки, a також сприятиме закріпленню Укрзалізниці на ринку транспортних послуг. У праці [2] розроблено методичний підхід до визначення раціональних зон курсування швидкісних та високошвидкісних поїздів, який додатково враховує: стан залізничної інфраструктури та можливість їі реформування; транзитний потенціал країни в пасажирському русі; стан економіки та економічний потенціал країни; привабливість інвестиційного клімату; платоспроможність різних прошарків населення; попит на користування залізничним транспортом та стан культури населення. Врахування цих факторів дозволить підвищити ефективність впровадження та експлуатації швидкісних і високошвидкісних поїздів.

Створення привабливих умов транспортного забезпечення в умовах розвитку швидкісного руху дозволить залучити на залізничний транспорт додатковий пасажиропотік 3 авіаційного та автомобільного транспорту, а також скоротити збитковість пасажирських перевезень на цих напрямках [3]. У роботі [4] розглядаються питання формування моделі прогнозування кореспонденцій потоків на залізничних лініях при впровадженні швидкісних пасажирських поїздів. Запропоновано процедуру настроювання моделі прогнозування на основі генетичного алгоритму 3 дійсним кодуванням. Проведені експериментальні дослідження підтверджують, що запропонована процедура настроювання $\epsilon$ стійкою, прийнятно складною та дозволяє підвищити точність прогнозування. На підставі проведеного аналізу у роботі [5] визначено, що найбільш прийнятним напрямком розвитку системи швидкісних залізничних пасажирських перевезень в Україні $€$ змішаний варіант розвитку мережі швидкісних сполучень на основі модернізації існуючих залізничних ліній для можливості руху пасажирських поїздів до 200 км/год. Даний підхід передбачає розвиток розгалуженої мережі спеціалізованих ліній, на яких поїзди здатні розвивати швидкість до 180 км/год 3 можливістю часткової взаємодії зі звичайною мережею. $\mathrm{y}$ роботі [6] розроблено методичний підхід щодо визначення оптимальних зон курсування пасажирських поїздів різних видів, який базується на зниженні їх експлуатаційних витрат та підвищенні швидкості руху при зміні організації руху за новою класифікацією поїздів, що дозволить підняти економічну ефективність або знизити збитковість пасажирських перевезень та підвищити їх конкурентоспроможність на ринку пасажирських транспортних послуг.

Для забезпечення інтеграції високошвидкісних ліній із звичайною залізничною мережею $\epsilon$ потреба в залізничних розв'язках. У праці [7] проведено дослідження 3 метою розробки сортувальної станції майбутнього, яка зможе полегшити обмін між високошвидкісною залізницею та звичайною. Розробки та можливості японських i французьких високошвидкісних магістралей проаналізовано у праці [8]. Результати, отримані у дослідженні, свідчать про те, що в більшості країн 
Свропи та США доцільно було б застосувати французьку модель для виконання пасажирських перевезень: $€$ схожість 3 точки зору географії, розподілу населення та відстаней. Усі проаналізовані роботи доводять, що висока швидкість залізничних перевезень є життєспроможним та привабливим способом організації перевезень.

Визначення мети та задачі дослідження. Метою роботи є формування цільової функції експлуатації швидкісних поїздів в Україні. Для реалізації зазначеної мети необхідно розглянути особливості розвитку швидкісного руху на мережі залізниць, визначити його переваги та розробити цільову функцію експлуатації швидкісних поїздів.

\section{Основна частина дослідження.} Велика провізна спроможність залізниць, стабільність їх роботи та порівняна дешевизна перевезень сприяли тому, що залізничний транспорт був і залишається в країні основним перевізником пасажирів у далекому та приміському сполученні.

Відповідно до Стратегії розвитку залізничного транспорту на період до 2020 р., схваленої Кабінетом Міністрів України у 2009 р., основними напрямами іiі реалізації $€$ : удосконалення технології організації перевезень шляхом організації руху поїздів за напрямками, які будуть орієнтовані переважно на один вид перевезень (пасажирські або вантажні); підвищення швидкості руху вантажних поїздів до 100120 і пасажирських - до 160-200 км/год; поетапне впровадження швидкісного руху пасажирських поїздів, насамперед за напрямками Київ - Донецьк, Київ - Харків, Київ - Одеса, Київ - Дніпропетровськ, Київ - Львів [9].

У 2012 році почалася активна реалізація певних напрямів стратегії впровадження на залізницях швидкісних перевезень. Основним етапом цього процесу було створення 22 лютого 2012 року «Української залізничної швидкісної компанії» - першої в Україні компанії 3 перевезення пасажирів денними швидкісними поїздами Інтерсіті.

На сьогоднішній день «Українська залізнична швидкісна компанія» - єдиний державний оператор пасажирських залізничних перевезень, в експлуатації якого знаходиться новітній рухомий склад: 10 електропоїздів виробництва компанії «Hyundai Rotem» (Республіка Корея) у дев' ятивагонній комплектації; два поїзди у складі по п'ять вагонів локомотивної тяги виробництва ПАТ «Крюківський вагонобудівний завод» (ПАТ «КВБЗ»); два двосистемні електропоїзди Екр-1 виробництва ПАТ «КВБЗ» у дев'ятивагонній комплектації. Мережа маршрутів компанії має дуже широкий спектр. Наразі вона об'єднує Київ 3 Запоріжжям, Дніпропетровськом, Харковом, Трускавцем, Одесою, Львовом та Тернополем.

Слід зазначити, що курс «Української залізничної швидкісної компанії» повністю узгоджується зі стратегією реформування галузі - сегментування залізничного транспорту за окремими напрямками діяльності. Швидкісна компанія створена 3 метою розширення та покращення комплексу послуг, що надаються пасажирам під час поїздки у швидкісних поїздах.

За чотири роки діяльності швидкісної компанії в Україні поїздами Інтерсіті+ та Інтерсіті скористалися понад 8 млн пасажирів [10]. У 2015 році перевезено понад 3 млн пасажирів, а середньомісячний пасажиропотік становить 256 тис. пасажирів. Влітку 2016 р. в Одеському напрямку поїздами Інтерсіті+ скористалися на $46 \%$ більше пасажирів, ніж минулого року - 187 тис. пасажирів. Також збільшилася і заповнюваність поїздів на 26,3 \% і досягла 96,4 \%.

$$
\text { Станом на березень } 2016 \text { p. }
$$
територією України курсувало 12 пар швидкісних поїздів, а це - 24 рейси щодня на маршрутах: Київ - Харків, Дарниця Львів, Дарниця - Трускавець, Київ Дніпропетровськ, Красноармійськ, Київ Запоріжжя, Київ - Костянтинівка, Дарниця - Тернопіль, Дарниця - Одеса. 
Отже, зростаючі обсяги пасажирських перевезень у швидкісних поїздах свідчать про те, що вони користуються чималим попитом у населення. Один із напрямків забезпечення подальшого зростання кількості перевезень для України - збільшення швидкостей руху пасажирських поїздів.

Сьогодні залізниці вже не повною мірою відповідають сучасним вимогам, які висуваються до транспорту, насамперед щодо тривалості поїздок. Незважаючи на вжиті за останні роки заходи 3 оновлення залізничних колій та рухомого складу максимально дозволена швидкість руху пасажирських поїздів на залізницях залишається порівняно невисокою - 120 км/год (крім напрямків Київ - Харків та Київ Дніпропетровськ з максимальною швидкістю руху 140 км/год). Маршрутна швидкість руху пасажирських поїздів на основних напрямках ще нижча (55-65 км/год) [11].

Аналізуючи міжнародний досвід, особливо японський, можна побачити, що зростання швидкісних перевезень йде досить швидкими темпами. В Європі все більше країн приділяють багато уваги розвитку високошвидкісного залізничного сполучення. Успіхи високошвидкісного руху в Свропі і Японії показують, що цей шлях дозволяє забезпечити потреби населення в перевезеннях 3 мінімальним впливом на навколишнє середовище. При цьому високошвидкісні поїзди успішно конкурують 3 авіаційним і автомобільним транспортом на відстанях 300-1000 км.

Визначено основні переваги від впровадження швидкісного пасажирського руху (рис. 1).

Основні переваги від впровадження швидкісного руху

Підвищення мобільності населення

Зниження собівартості перевезень та підвищення їх якості

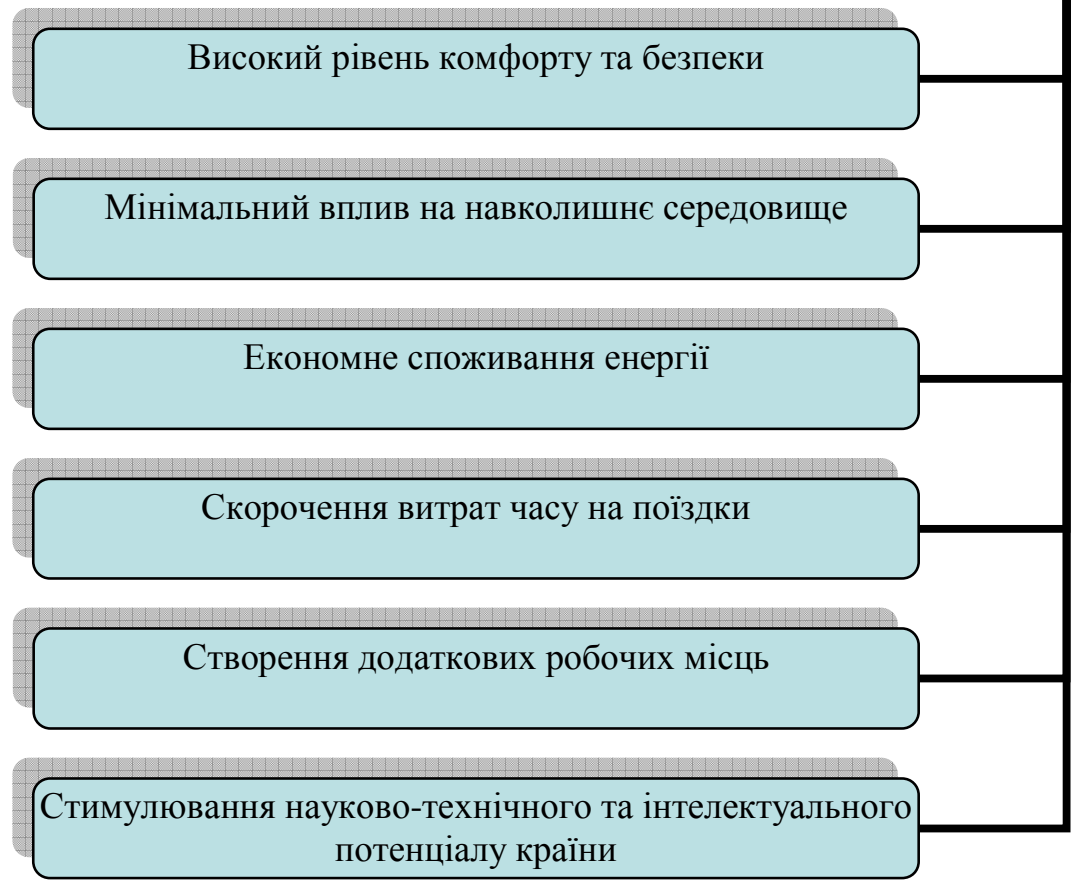

Рис. 1. Основні переваги від впровадження швидкісного пасажирського руху 
При п підвищенні мобільності населення час у дорозі між столицями регіонів складає в середньому 1 год i суттєво підвищить економічну активність і трудову міграцію. Зниження собівартості перевезень та підвищення їх якості за рахунок поділу ліній пасажирського i вантажного руху забезпечить зростання пропускних спроможностей високозавантажених напрямків і зниження інвестиційних витрат на розширення існуючої інфраструктури. Високий рівень комфорту забезпечується за рахунок сучасного рухомого складу із затишним інтер'єром, який створено 3 урахуванням всіх законів ергономіки. До того ж швидкісні поїзди мінімально впливають на навколишнє середовище в порівнянні з іншими видами транспорту.

Енергоефективність швидкісних поїздів може досягти нового рівня вже сьогодні завдяки проведенню заходів, спрямованих на поліпшення технології виробництва поїздів і методів управління пересуванням по залізницях. Розробляючи графіки руху, фахівці розраховують необхідну кількість часу для даного маршруту i плюс додатковий час, який може використовуватися при запізненні складу або для економії енергії. Також враховується i той факт, що при максимальній швидкості витрачається мінімальна кількість часу i максимальне споживання енергії.

Організація швидкісного руху забезпечує підтримку i подальше стимулювання науково-технічного та інтелектуального потенціалу країни за рахунок розміщення на вітчизняних підприємствах замовлень на створення нових зразків техніки світового рівня.

Для ефективної експлуатації швидкісних поїздів необхідною умовою $\epsilon$ мінімізація сукупних експлуатаційних витрат. Тому цільову функцію доцільно подати як суму приведених витрат на один швидкісний поїзд в залежності від середньої швидкості руху при безупинному пропуску швидкісного поїзда

$$
R(V)=Z_{M} C_{m \kappa M}+\frac{L C_{n-2}}{\alpha_{M} V} \rightarrow \min ,
$$

де $Z_{м}$ - механічна робота локомотива, що витрачається на переміщення поїзда, ткм;

$C_{m \kappa м}-$ вартість 1 т-км механічної роботи локомотива, грн;

$L$ - відстань перевезення, км

$C_{n-2} \quad-\quad$ вартість поїздо-години швидкісного поїзда, грн;

$\alpha_{м}$ - коефіцієнт маршрутної швидкості, можна прийняти $\alpha_{M}=0,9$;

$V$ - середня швидкість руху поїзда без урахування зупинок i витрат часу на розгони і уповільнення, км/год.

Механічну роботу локомотива можна визначити таким чином:

$$
Z_{м}=Q L+Q V K_{3},
$$

де $Q$ - маса поїзда брутто, т;

$K_{3}$ - кількість зупинок швидкісного поїзда.

Вартість поїздо-години швидкісного поїзда

$$
C_{n-2}=\sum C_{b-2} n+C_{n} r_{H}+k_{\pi} C_{\pi-2}+k_{\sigma p} C_{\sigma p-2}^{\pi}+k_{n p} C_{\sigma p-2}^{n p},
$$

де $C_{b-2}, C_{\pi-2}-$ вартість вагоно- та локомотиво-години відповідно, грн;

$n$ - число вагонів у составі;
$C_{n}$ - вартість 1 пас.год, грн;

$r_{H}$ - розрахункова населеність швидкісного поїзда; 
$k_{л}, k_{б p}, k_{n p}-$ коефіцієнти, що враховують час позапоїзної роботи, локомотива, локомотивної бригади і бригади провідників відповідно;
$C_{\sigma p-2}^{\pi}, C_{б p-2}^{n p}-$ вартість 1 год роботи локомотивної бригади і бригади провідників відповідно, грн.

Таким чином, оптимальне значення середньої швидкості руху визначається мінімальним значенням цільової функції

$$
\begin{gathered}
R(V)=\left(Q L+Q V K_{3}\right) C_{m \kappa м}+ \\
+\frac{L\left(\sum C_{B-2} n+C_{n} r_{H}+k_{\pi} C_{\pi-2}+k_{\sigma p} C_{6 p-2}^{\pi}+k_{n p} C_{\sigma p-\tau}^{n p}\right)}{\alpha_{M} V} \rightarrow \min .
\end{gathered}
$$

Реалізація функції показала, що для усереднених вихідних даних можливо отримати оптимальне значення середньої швидкості руху при безупинному пропуску швидкісного поїзда - 160 км/год при мінімальних витратах 7023,42 грн (рис. 2).

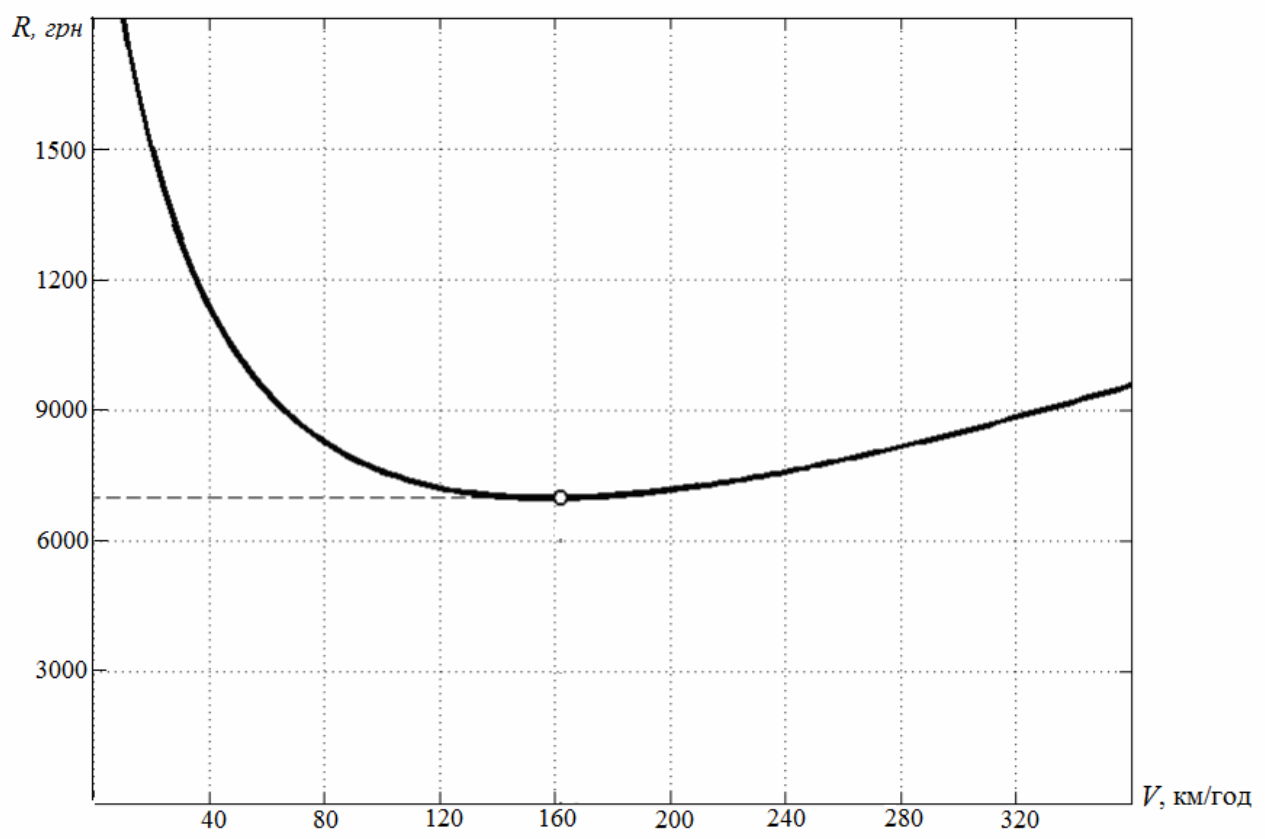

Рис. 2. Залежність сукупних витрат на один поїзд від середньої швидкості руху

Отже, спираючись на проведені дослідження, переваги швидкісних перевезень та світовий досвід, можна стверджувати, що для України буде доцільним та вигідним подальше впровадження швидкісних перевезень на всіх густонаселених напрямках. Згодом можливе поетапне збільшення швидкості руху поїздів спочатку до 200 км/год, а потім і понад 200 км/год (високошвидкісний рух), але це потребує додаткових капіталовкладень в інфраструктуру, 
пов'язаних 3 побудовою спеціально виділених залізничних колій - високошвидкісної магістралі (ВШМ). Досвід усіх здійснених проектів ВШМ у світі показав, що в транспортних коридорах після початку експлуатації високошвидкісних поїздів відбувається перерозподіл пасажиропотоку на користь саме високошвидкісного залізничного транспорту.

Висновки 3 дослідження і перспективи, подальший розвиток у даному напрямку. Таким чином, розглянуто організацію швидкісних залізничних перевезень в Україні та встановлено, що сьогодні залізниці вже не повною мірою відповідають сучасним вимогам, які висуваються до транспорту, насамперед щодо тривалості поїздок. Максимальна дозволена швидкість руху пасажирських поїздів на залізницях залишається невисокою у порівнянні 3 європейськими залізницями. Аналіз обсягів перевезень пасажирів довів, що одним із напрямків забезпечення подальшого зростання кількості перевезень $є$ збільшення швидкостей руху пасажирських поїздів. Тому визначено оптимальне значення середньої швидкості руху при безупинному пропуску швидкісного поїзда - 160 км/год при мінімальних витратах 7023,42 грн. Відповідно до виконаних досліджень та міжнародного досвіду встановлено, що для України буде доцільним та вигідним подальше впровадження швидкісних перевезень.

\section{Список використаних джерел}

1. Корінь, М. В. Організація високошвидкісного руху як фактор забезпечення конкурентних переваг залізничного транспорту України [Текст] / М.В. Корінь // Вісник економіки транспорту і промисловості. - 2011. - № 34. - С. 189-194.

2. Момот, А.В. Методичний підхід до визначення раціональних швидкостей руху пасажирських поїздів та раціональних зон їх курсування [Текст] / А.В. Момот // Проблеми економіки транспорту: зб. наук. праць Дніпропетровського національного університету залізничного транспорту імені академіка В. Лазаряна. - 2013. - Вип. 5. - С. 80-89.

3. Кішко, О. В. Удосконалення перевезення пасажирів при розвитку залізничного швидкісного руху [Текст] / О.В. Кішко, Г.М. Сіконенко // Зб. наук. праць Укр. держ. акад. залізнич. трансп. - Харків: УкрДАЗТ, 2013. - Вип. 140. - С. 55-59.

4. Пархоменко, Л. О. Процедура формування моделі прогнозування пасажиропотоків на залізничних лініях [Текст] / Л.О. Пархоменко // Восточно-Европейский журнал передовых технологий. - Харьков, 2013. - Вып. 5/4 (65). - С. 7 - 10.

5. Пархоменко, Л. О. Дослідження напрямків розвитку швидкісного і високошвидкісного пасажирського руху поїздів на залізницях України [Текст] / Л.О. Пархоменко // Зб. наук. праць Укр. держ. акад. залізнич. трансп. - Харків: УкрДАЗТ, 2014. - Вип. 145. - С. 44-50.

6. Бараш, Ю. С. Методичний підхід щодо визначення оптимальних зон курсування різних видів пасажирських поїздів [Текст] / Ю.С. Бараш, О.О. Матусевич // Вісник економіки транспорту і промисловості. - 2015. - Вип. 50. - С. 169-176.

7. Abbott $\mathrm{D}$. An event based simulation model to evaluate the design of a rail interchange yard, which provides service to high speed and conventional railways [Text] / D. Abbot, M. Varbanov-Marinov // Simulation Modelling Practice and Theory. - 2015. - Vol. 52. - P. 15-39.

8. Palacin R. High speed rail trends, technologies and operational patterns: a comparison of established and emerging networks [Text] / R. Palacin, L. Raif, Ö. Deniz., N. Yan // Transport Problems INTERNATIONAL SCIENTIFIC JOURNAL. - 2014. - Volume 9. Special Edition. P. $123-129$. 
9. Транспортна стратегія України на період до 2020 року [Електронний ресурс] / Розпорядження Кабінету Міністрів України від 20.10.2010 р. № 2174-р. - Режим доступу: http://zakon5.rada.gov.ua/laws/show/1555-2009-\%D1\%80.

10. За чотири роки роботи Української залізничної швидкісної компанії швидкісними поїздами скористалися понад 8 мільйонів пасажирів [Електронний ресурс]. - Режим доступу: http://www.magistral-uz.com.ua/news/za-chotiri-roki-roboti-ukrainskoi-zaliznichnoi-shvidkisnoikompanii-shvidkisnimi-poizdami-skoristalisja-ponad-8-miljoniv-pasazhiriv.html.

11. Про схвалення Концепції Державної цільової програми впровадження на залізницях швидкісного руху пасажирських поїздів на 2005-2015 роки / Розпорядження Кабінету Міністрів України від 31 грудня 2004 р. N 979-р [Електронний ресурс]. - Режим доступу: http://zakon2.rada.gov.ua/laws/show/979-2004-\%D1\%80.

Бауліна Ганна Сергіївна, канд. техн. наук, доцент кафедри управління вантажною і комерційною роботою Українського державного університету залізничного транспорту. Тел.: (057)730-10-85.

Левченко Валентин Сергійович, магістр групи МЗ-TEMPUS-ОПУТ-Б15, Український державний університет залізничного транспорту. Тел.: (057)730-10-85.

Baulina Ganna, PhD. sc., associate professor of the department of freight and commercial work, Ukrainian State University of Railway Transport. Tel.: (057)730-10-85.

Levchenko Valentin, master of the group M3-TЕMPUS-ОПУТ-Б15, Ukrainian State University of Railway Transport. Tel.: (057)730-10-85.

Стаття прийнята 26.09.2016 р. 